\title{
A SAPARD PROGRAM SZEREPE A MEZŐGAZDASÁGI VÁLLALKOZÁSOK EU INTEGRÁCIÓJÁBAN
}

\author{
(The Role of the SAPARD Programme in the EU Integration \\ of the Agricultural Enterprises)
}

\section{LEITMANN ÁLMOS PÉTER}

Napjainkban a világra egyre inkább jellemző a globalizáció, melynek hatásai mindenre kiterjednek. Kérdésként merül fel, hogy a régióknak hogyan kell belevágniuk ebbe a globalizációs hajszába, hogy minél inkább nyertesként kerüljenek ki belöle, de esetleges veszteségeik se legyenek romboló hatással a kultúrára és a hagyományokra. Tanulmányunkban erre a kérdésre nem a választ keressiuk, hanem a lehetöségeket szeretnénk felvázolni.

Magyarországon a mezőgazdaság nemzetgazdaságban betöltött szerepe az elmúlt évtizedekben fokozatosan csökkent. A mezögazdaság súlya - folyó áron számolva - 1994-ben a GDP-böl 6\%-ot tett ki, 1998-ra a mezögazdasági GDP aránya 5\%-ra mérséklödött. Az EU tagországokban - Görögország és Írország kivételével - ez az arány 1-5\% között van. Az élelmiszeriparral együtt a nemzetgazdaságon belüli GDP-arány már 9-10\%, míg az egész agrobusiness-re vetítve 15-18\%-ot mutat.

Az EU-ban használt kritériumok szerint az összes terület dőntő hányada $(96,1 \%)$ vidéki térségnek minősül, ahol a népesség közel háromnegyede $(73,6 \%)$ él. Magyarországon az alapvetóen vidéki térségek területi aránya $61,5 \%$, ami lényegesen meghaladja az Unió hasonló jellemzőjét (47\%); e területek összes népességböl való részesedése pedig 3,5-szer nagyobb az uniós tagországokban mérhetô hányadnál. $\mathrm{Az}$ alapvetően és a jellemzően vidéki térségekben élő népesség aránya együttesen 34\%-kal magasabb hazánkban, mint az Unió átlagában, amely Magyarország sajátos településszerkezetére vezethető vissza.

\section{TÁBLÁZAT}

Mezőgazdasági aktiv keresők kor és iskolai végzettség szerinti összetétele (\%) (Persons Employed in Agriculture by Age and Level of Education)

\begin{tabular}{lrc}
\hline \multicolumn{1}{c}{ Kor szerinti megoszlás } & 1990 & 1998 \\
\hline $14-29$ éves & 23,5 & 21,8 \\
30-39 év & 31,0 & 25,9 \\
40-54 év & 38,6 & 46,7 \\
55 év felett & 6,9 & 5,6 \\
Összesen & 100,0 & 100,0 \\
\hline Iskolai végzettséég szerinti összetétel & & \\
\hline Általános iskolai végzettség & 55,3 & 42,4 \\
Középiskolai végzettség & 39,2 & 50,4 \\
Felsöfokú végzettség & 5,5 & 7,2 \\
Összesen & 100,0 & $I 00,0$ \\
\hline
\end{tabular}

Forrás: KSH. 
Az agrárgazdaságban az Európai Unióhoz viszonyítva, rendkívül alacsony a jövedelmezőség. 1997-ben a 100 Ft befektetett eszközre jutó adózás előtti eredmény $6,5 \mathrm{Ft}$, a $100 \mathrm{Ft}$ saját tőkére jutó eredmény $5,2 \mathrm{Ft}$ volt. Hiába részesedik a nemzetgazdasági beruházásokból EU-s szinten, a korábbi évek fejlesztési hiányosságait képtelen kiküszöbölni, és eszközállományát megújítani. Az is sújtja az agrárgazdaságot, hogy az 1990 és 1997 közötti idöszakban az ipari termékek árindexe 405\%kal nőtt, míg a mezőgazdasági termékek felvásárlási ára mindössze 195\%-kal.

\section{Az EU szempontjainak érvényesitése a csatlakozás küszöbén}

Az Európai Unió a csatlakozás feltételeként három, igen tág szempontot határozott meg:

1) szilárd demokrácia, müködö piacgazdaság;

2) politikai jogrend;

3) emberi jogok.

Ezeknek a feltételeknek a teljesüléséhez szükséges a közösségi vívmányok (acquis communautaire) átvétele is. Ezek tartalmazzák mindazokat az EU által 40 év alatt megalkotott jogszabályokat és intézkedéseket, amelyek kötelező érvényủek mindenki számára.

A termelés legfontosabb paramétere a minöség. Az EU-ban minden támogatási rendszer minöséghez kötött. Ezeknek a követelményeknek való megfelelés alapvetó fontosságú a mezőgazdasági termelés szempontjából. Pl. az EU-ban fogyasztói tejnek csak az felel meg, aminek csíraszáma 100 ezer és szomatikus sejtszáma 400 ezer maximum (ml-ként $30^{\circ} \mathrm{C}$-on). Magyarországon e normának csak az extra minöségủ tej felel meg.

A közösségben a gazdaságok átlagos területe 14 ha. A görög és a portugál gazdaságok méretei, melyek gazdálkodása és fejlettsége legközelebb áll a csatlakozó országokéhoz, 4 ha illetve 6,7 ha. Ezek a számok is messze meghaladják a mostani hazai átlagot. Erre azért kell nagy figyelmet fordítani, mert az Unió a túl kicsi gazdaságokat nem veszi árutermelő gazdaságként számba, és ebben az esetben a vonatkozó támogatásoktól elesnek.

A szociális és gazdasági biztonsági háló miatt rendkívưl fontos lenne a csatlakozás mielöbbi lezajlása, ugyanis az EU által biztosított szociális juttatások és támogatások a gazdálkodóknak jelentős segítséget nyújtanának.

\section{A SAPARD program és az ehhez kapcsolódó csatlakozást megelözö segélyek}

A mezógazdasági vállalkozások számára a jelen pillanatban rengeteg forrás áll rendelkezésre, az EU-hoz való csatlakozás negatív hatásainak csökkentésére. Ilyenek a PHARE, a SAPARD és az ISPA.

Tudni kell, hogy az EU mezógazdasági politikája átalakulóban van éppúgy, mint az egész EU maga, és ehhez a változó politikához kell alkalmazkodnia a csatlakozó 
országoknak. Ezek a változások elsősorban a mezőgazdasági vállalkozások támogatási formáiban mennek végbe. Az Agenda 2000-ben fogalmazták meg elöször azt az irányvonalat, ami mentén a változtatásokat végre kell hajtani. Az Agenda legföbb céljai a következők:

- Piacfejlesztés: a fenyegetően tornyosuló többletek csökkentése és megszủntetése;

- A támogatási rendszer újragondolása: a szubszidiaritás elve alapján és a közvetlen jövedelemtámogatásokkal;

- A bővítés: fokozottan fenyegető többlettermelés, valamint az ártámogatás és a közvetlen kifizetések fenntarthatatlansága;

- Más célok: a mezőgazdaság és a környezet harmóniája; az élelmiszerbiztonság javítása és nem utolsó sorban az állatvédelem.

\section{Támogatási formák változása a különbözö ágazatok esetében}

\section{Szántóföldi növények}

Az intervenciós árakat 20\%-kal csökkentik ebben az évben. A gabona „biztonsági hálót" 95,35 euró/t-ban határozták meg, amelyet havonta felülvizsgálnak és minőség szerint differenciálnak. A közvetlen kifizetések 66 euró/t, ez azonban csökkenni fog az intervenciós ár 50\%-ával. Fontos, hogy a gabona, az olajos magvak és a nem textilipari lenmag egy elbírálás alá került. A fehérjenövények területalapú támogatása 72,5 euró/t. A kötelező területkivonás, a „set aside”, megmaradt. Az önkéntes területkivonás engedélyezett, de gabona terület alapú támogatási feltételekkel.

\section{Marhahús}

A piaci intervenció helyére a magántárolási segély lépett. A valós piactámogatási szintet 30\%-kal kell csökkenteni. A jelenlegi intervenciós árat 10-10\%-kal kell csökkenteni 2000., 2001. és 2002. július 1.-ig. Ettől kezdve 1950 euró/t magántárolási segély lép életbe. Az állatlétszám alapú kifizetés megnövekedett. Speciális prémiumot kapnak: a bikák - 220 euró, ökrök - 170 euró. A borjas tehén prémiuma 180 euró. Az EU által ebben az esetben meghatározott „,nemzeti plafon” az 1995. és 1996. év jobbika és még 3\%. Adnak tejelőtehén prémiumot is, ami 35 euró/tehénegység $(5800 \mathrm{~kg})$, valamint 35 euró kiegészítő tejhozam prémium a ,nemzeti borítékból”. Vannak még az állatsürüség korlátok, amely 2 élöállat egységet tesz lehetővé takarmányterület-hektáronként; az 1,4 élőállat egység alatti területek még 100 euró prémiumban részesülnek.

Mit is jelent az előbb említett nemzeti boriték? A tagország által meghatározott kritériumok alapján fizetett pótlólagos támogatás. Az alapprémium növelés csak 50\%-os, a támogatási rendszer változásából adódóan, a másik 50\% a nemzeti borítékba kerül. 
Tej

A vaj és a sovány tejpor intervenciós ára négy alkalommal, összesen 15\%-kal lesz csökkentve. A kvótarendszer minimum 2006-ig fennmarad. Van azonban lehetöség a kvóta növelésére $2 \%$ erejéig, amiböl $1 \%$ a hegyvidéki, sarkvidéki termelöknek, $1 \%$ pedig a fiatal gazdálkodóknak jut. A közvetlen segély kifizetések növekednek; az egy tehénre jutó alaptámogatás 4 lépésben növelve 100 euró lesz 2003-ban; ezt viszont a tagország a nemzeti borítékból 145 euró-ra növelheti. A termelönként kifizetett közvetlen segély összege a támogatott egységeken alapul (a termelỏ saját kvótája osztva az Unió átlagos tejhozamával). E a segély összege tejelö tehenenként hozzáadódik a húsmarha prémiumhoz.

\section{Az Európai Mezögazdasági Modell}

Azért fontos egy ilyen modell megfogalmazása és követése, hogy a csatlakozni vágyó illetve a csatlakozás küszöbén levő országok tudják, hogy milyen elvárásai vannak az Uniónak a csatlakozó országok mezögazdasági vállalkozásaival szemben. Másodsorban pedig azért, mert egy így megalkotott modell segítségével a támogatási struktúra átalakítása könnyebb lesz, és végeredményként egy átláthatóbb rendszer jön létre.

A modell föbb elemei a következők:

- versenyképes mezőgazdasági szektor, amely szembe tud nézni a világpiac kihívásaival, anélkül, hogy túltámogatott lenne;

- megalapozott és környezetbarát termelési módszerek a lakossági igényeknek megfelelő minőségi termék elöállitás;

- sokszínủ és gazdag hagyományokkal rendelkező mezőgazdaság, amely megörzi és ápolja a vidék képét, a vidéki települések mozgalmas és érdekes életét, munkalehetőségeket biztosít, illetve újakat teremt;

- egyszerübb és jobban érthető agrárpolitika, hogy a költségeket igazolja az „ellen"-szolgáltatás;

- többfunkciós mezőgazdaság jöjjön létre.

Az európai mezőgazdasági modell védelmezi a farmerek jövedelmét, és stabilitást biztosít számukra a piacszabályozás és a kompenzációs kifizetések révén. Jelentős szerepet szánnak a mezögazdaságnak a gazdaságban, a környezetvédelemben, a társadalomban és a táj megóvásában.

Eddig az Európai mezögazdasági modell a rossz hatásfokú mezögazdaság takargatására szolgált, amit nagy összegủ támogatásokkal segítettek.

$\mathrm{Az}$ EU a csatlakozásra váró országoknak létrehozott egy úgynevezett csatlakozást megelózó segélyek alapot. Ebből Magyarország a SAPARD program keretén belül, amely a mezőgazdaság és a vidék fejlesztését támogatja 2000-2006-ig, évi 38,054 millió euró támogatásban részesül. Szintén ilyen segély az ISPA (Instrument for Structural Policies for Pre-Accession), melynek fő célja a csatlakozásra váró országok felkészítése a Strukturális Alapok támogatásának fogadására, valamint az infrastruk- 
túra és a környezetvédelem területén a csatlakozást hátráltató konkrét problémák megoldására.

Visszatérve a SAPARD-hoz, a program támogatási célterületei az agrárvállalkozások, farmigazgatási szolgáltatások, a feldolgozottság és az értékesithetöség javitása, az állat- és növény-egészségügyi ellenörzés javitása, az alternativ jövedelemszerzés, a falu- és vidékfejlesztés (infrastruktúra, müemlék), a talajjavitás, a parcellázás, a földnyilvántartás kialakitása, a szakképzés, a vízgazdálkodás, az erdészet és az agrár-környezetvédelem. A SAPARD program célja a vidéki régió komplex segítése a vidékfejlesztésen és az agrárstruktúra átalakításán keresztül. Ezen belül az életminőség általános javítása a vidéki térségekben az önkormányzati, civil és vállalkozói szféra bevonásával és azok fejlesztésével.

Minden EU által meghirdetett program igényel saját forrást is, ugyanis az EU a megpályázott programok 75\%-át finanszírozza általában, ettől lehet eltérés; különleges esetekben a támogatás mértéke lehet $85 \%$, vagy nagyon ritkán elérheti a $100 \%$-ot. Annak következtében, hogy a programok végrehajtásához saját részt is hozzá kell adni, a mezögazdaságba begyürüző friss tőke nagysága a keret többszöröse lesz.

Ezekben a programokban való aktív részvétel a mezögazdasági vállalkozásoknak nagy esélyt adhat az Unióba való integrálódás zökkenömentessé válásához. Ehhez azonban összefogásra, közös cél és stratégia megfogalmazására, regionális és kistérségi együttmüködések kialakítására van szükségük, mert a kisvállalkozások egymagukban esélytelenül pályáznak forrásokra, de életképtelenek lesznek az Unió gazdasági forgatagában is. Erre példa az is, hogy a sok őstermelỏ például az Unióban semmilyen támogatásra nem számíthat, mert ilyen gazdálkodási formát az EU nem ismer, és azért sem, mert gazdálkodási méretük túl kicsi.

Azon gazdaságoknak is, amelyek megfelelnek az Uniós méretkövetelményeknek, lehet problémájuk az EU piacain, mert a minöségi termék elóállítás területén rengeteg a pótolnivaló.

A SAPARD programra beérkezö összegek felosztása a következöképpen valósul meg: 1 . évben $60 \%$ a mezőgazdaságra, $40 \%$ a vidékfejlesztésre fordítható hányad, és ez az arány csak a 3. évben fordul meg.

Látható, hogy a program egy komplex támogatási rendszer, amely nem csak termelésbővítő támogatást ad, hanem a Strukturális Alapoknak megfelelö formában nyújt segítséget az elmaradott térségeknek. Az Unióban elmaradott térségnek számít az, amelyiknek GDP-je nem éri el a közösségi átlag 75\%-át. Ezt Magyarországon csak Budapest súrolja alulról, az összes többi 30 és $40 \%$ között mozog. Ennek következtében az ország egész területe jogosult ezekre a támogatásokra.

Ahhoz, hogy a mezőgazdasági vállalkozások felvehessék a versenyt az EU-ban hasonló területeken müködö vállalkozásokkal, mindenképp szükségük van a támogatások igénybevételére. Ha ezzel versenyképességük nem is éri el azt a szintet, hogy harcba szálljanak teljes mértékben az Unió piacaiért, de legalább felkészülnek arra, hogy a támogatások pályázása és igénybevétele hogyan müködik. 
Felvetödhet a kérdés, hogy célja-e az EU-nak az, hogy a csatlakozó országok mezőgazdasága versenyképes legyen az Unió piacán? Az egyik lehetséges válasz az, hogy nem, mert az Unióban így is többlettermelés van sok mezögazdasági termékböl és ezeknek nem versenytárs kell, hanem piac. A másik lehetöség pedig éppen ennek az ellenkezője, vagyis igen; éspedig azért, mert az Unióba érkező sok-sok versenyképes mezőgazdasági vállalkozás következtében majd egy olyan ösztönzöerỏ lép fel, amely a termelés hatékonyságát növeli, és ezzel egy ütemben a túlzott támogatások, amelyek a költségvetés reformját is elöidézték, nagymértékben csökkenthetök lesznek. Amennyiben az előbbi politikát választja az EU, úgy a csatlakozó országok mezögazdasági vállalkozásainak nem sok esélye van, és csak az eddig is hatékony és gazdaságosan termelők fognak profithoz jutni, a többiek pedig kilátástalan helyzetbe kerülnek. Ha az utóbbi politika a mérvadó, akkor viszont mindenkinek meg kell ragadnia az esélyt, hogy még a csatlakozás előtt a támogatások igénybevételével vállalkozását hatékonnyá és versenyképessé tegye, mert csak így lesz lehetősége a szigorú Uniós szabályozások közötti helytállásra.

\section{Irodalom}

Halmai P. (1995) Az Európai Unió agrárrendszere. Budapest, Mezőgazda Kiadó.

Magyarország SAPARD terve 2000-2006. (1999) Budapest, FVM.

\section{THE ROLE OF THE SAPARD PROGRAMME IN THE EU INTEGRATION OF THE AGRICULTURAL ENTERPRISES}

\section{ÁLMOS PÉTER LEITMANN}

Today the regions have got a lot of opportunities to receive money from the EU. They have to take the opportunity to close the gap between the regions of the EU, so they will have the possibility to be competitive. The money from the EU is not much $(38,054$ million Euro), but as the EU declared, this money is not for the enlargement of production. This must be prepared first for the EU's Structural Founds.

The first and the most important thing is the quality in the harmonization of agricultural production with EU regulations. A lot of subsidies are differentiated by quality. If the farmers do not realize the significance of quality, they will miss a lot of money.

Ten countries are going to join the EU and all of them have different strategies. The EU also has their own strategy and adjustment to this new changing strategy is essential for the farmers and the entire agricultural sector. 